\title{
Spatial distribution, bioavailability, and toxicity of metals in surface sediments of tropical reservoirs, Brazil
}

\author{
Daniele Frascareli - Sheila Cardoso-Silva • Juliana de Oliveira Soares-Silva Mizael • \\ André Henrique Rosa • Marcelo Luiz Martins Pompêo • Julio Cesar López-Doval • \\ Viviane Moschini-Carlos
}

Received: 27 August 2017 / Accepted: 29 January 2018 /Published online: 8 March 2018

(C) Springer International Publishing AG, part of Springer Nature 2018

\begin{abstract}
Depending on the environmental conditions, surface sediments can retain all the contaminants present and provide a record of the anthropic activities affecting the aquatic environment. In order to analyze the impacts on reservoirs, surface sediments were collected in three characteristic regions (riverine, transitional, and limnetic zones) of seven reservoirs in São Paulo State, Brazil. Analyses were made of grain size, organic matter (OM), total phosphorus (TP), and total nitrogen (TN). Inductively coupled plasma-atomic emission spectroscopy (ICP-AES) was used to determine pseudo-total and bioavailable metals $(\mathrm{Cu}, \mathrm{Cd}, \mathrm{Cr}, \mathrm{Ni}, \mathrm{Pb}, \mathrm{Zn}, \mathrm{Mn}, \mathrm{Fe}$, and $\mathrm{Al}$ ). A Horiba probe was used to measure dissolved oxygen (DO), $\mathrm{pH}$, redox potential (ORP), and temperature (Temp) in the bottom water. The data were analyzed
\end{abstract}

Electronic supplementary material The online version of this article (https://doi.org/10.1007/s10661-018-6515-8) contains supplementary material, which is available to authorized users.

D. Frascareli $(\bowtie) \cdot$ S. Cardoso-Silva •

J. de Oliveira Soares-Silva Mizael · A. H. Rosa •

V. Moschini-Carlos

São Paulo State University-UNESP, Avenida Três de Março 511, Alto da Boa Vista, Sorocaba, SP 18087-180, Brazil

e-mail: dani.frascareli@hotmail.com

M. L. M. Pompêo

Ecology Department, São Paulo University-USP-IB, R. do Matão, Travessa 14, 321, Butantã, Sao Paulo, SP 05508-090, Brazil

J. C. López-Doval

Department of Evolutionary Biology, Ecology and Environmental Sciences, University of Barcelona, Avinguda Diagonal, 643, 08028 Barcelona, Spain using multivariate statistics. Enrichment factors (EF), pollution load index values (PLI), and background values $(\mathrm{BG})$ were also determined in order to evaluate the potential toxicity. Intra-reservoir and inter-reservoir spatial heterogeneity $(p<0.05)$ were observed using two-way analysis of similarities. Principal component analysis indicated greater influence of metals in the Barra Bonita, Salto Grande, and Rio Grande reservoirs, corroborating the PLI, EF, and BG data. Bioavailable $\mathrm{Cu}$ was found in the Rio Grande reservoir, possibly associated with copper sulfate used to control algal blooms, while bioavailable $\mathrm{Ni}$ in the Barra Bonita reservoir was attributed to the presence of industrial wastes and natural geology. The bottom water conditions indicated that the metals remained in insoluble forms.

Keywords Surface sediment · Metals · Tropical reservoirs

\section{Introduction}

Metals are an important class of pollutants that can cause adverse effects, depending on concentration and the environmental conditions (Iqbal et al. 2016). The sources of metals can be lithologic, biotic, or anthropogenic (Zahra et al. 2014). Lithologic sources include rock weathering and the erosion of margins. Biotic sources involve processes such as bioturbation/ bioirrigation (He et al. 2017). Anthropogenic sources include inputs associated with discharges of domestic and industrial effluents, agricultural activities, and 
atmospheric deposition (Superville et al. 2015; Wang et al. 2015; Tzoraki et al. 2015).

When they enter aquatic ecosystems, especially reservoirs, metals can cause toxic effects, accumulate in flora and fauna, be transported to other water bodies, and contaminate foods consumed by humans (Arnason and Fletcher 2003; Sundaray et al. 2011; US EPA 2016). In some cases, bioaccumulation and biomagnification can occur. Metals interact with the abiotic components of the ecosystem and tend to precipitate and accumulate in sediments (Zhang et al. 2016).

Tributaries, nutrient loads, sediment transport, morphology, hydrology, allochthonous or autochthonous organic matter, water discharge for electricity generation or public supply, and seasonal pulses can all affect the residence time of the water, cause spatial compartmentalization of reservoirs, and determine both lotic and lentic characteristics, favoring the formation of longitudinal gradients (Thornton et al. 1990). According to the theory of Thornton et al. (1990), higher metals and nutrient concentration are expected to be observed in the dam area due to sedimentation patterns. The low velocity of water characteristic of this area reflects the settling of both fine and colloidal material, which has an important adsorption capacity for these elements. On the other hand, the river zone, where sedimentation of sand and coarse silt occurs, turbidity minimizes light penetration, and the land uses, influences the loading of sediment and organic matter to reservoir. The transition zone has an intermediate characteristic of sorption which is not as high as in the dam zone; in this region, adsorption process of metals, nutrients, and dissolved organic compounds is initiated (Thornton et al. 1990). Several studies have identified the capacity of reservoirs to self-purify due to the decrease of water velocity from upstream to downstream (Wei et al. 2009; Gao et al. 2016). However, other studies have found high concentrations of metals in the dam area, associated with anthropic activities in the regions surrounding reservoirs (Bing et al. 2016; Zhu et al. 2017). Therefore, despite the capacity of reservoirs to self-purify, pressures exceeding the environmental support capacity can put both ecological equilibrium and ecosystem services at risk.

The sediment acts as a sink for contaminants (Zhu et al. 2017). However, depending on the environmental conditions, metals can become resuspended in the water column (Förstner and Wittman 1983) and represent a diffuse source of pollution. Furthermore, the sediment may also play an important role in the trophic dynamics of the ecosystem, by means of geochemical interactions between the water column and the sediment, including the release of nutrients (Mayer et al. 2006). Studies of the surface sediments, together with the bottom and/or column water, can be used for elucidation of the temporal and spatial dynamics of contaminants and for evaluation of the effectiveness of reservoir management. Of special concern is the metal contamination assessment in sediments. Several lines of evidence have been applied in order to assist in decision-making processes and in the management of reservoirs with contaminated sediments. Some of the recognized lines of evidence applied in the scientific literature are the empirical sediment quality guideline values (SQGV), ISQG (interim sediment quality guideline), PEL (probable effect level) (CCME 1999), the enrichment factor (EF) index (Sutherland 2000), and the pollution load index (PLI) (Tomlinson et al. 1980).

This research is part of a broader project that aims to adapt the European water resource management criteria (provided in the European Union Water Framework Directive) to Brazilian conditions. According to European regulation EC 60/2000 (CIS 2000), the first step is to establish a typology based on abiotic factors for each type of water body. The application of the typology is based on the hypothesis that different abiotic conditions result in distinct biological and ecological characteristics. The reservoirs studied here were selected based on a previous study conducted by Cardoso Silva et al. (submitted for publication), who proposed a typology for São Paulo State reservoirs, distinguishing four types of reservoir (I, II, III, and IV). The authors established the classification based on the following abiotic variables: longitude, latitude, altitude, reservoir size and average depth, annual precipitation average, and the drainage basin area. This work presents data for seven reservoirs of two types (I and II). The type (I) reservoirs are located in the eastern part of São Paulo State, with the highest elevations and the highest historical average rainfall. The values of these variables decrease progressively for the type (II) reservoirs located between the eastern and western regions of São Paulo State, which are generally larger and have more extensive drainage basins, compared to the type I reservoirs. The hypothesis adopted in this work was that different abiotic conditions result in distinct biological and ecological characteristics. 
This study represents part of an analysis of the pressures and impacts on these water bodies in accordance with the Water Framework Directive recommendations. The current research had two main objectives. The first one was to investigate the spatial heterogeneity of metals, nutrients, and sediment quality in the main theoretical compartments of reservoirs, namely the river, transitional, and dam zones (Thornton et al. 1990), in order to assess if these areas were in fact distincted among them according to Thornton's assumptions and to evaluate the spatial heterogeneity between different reservoirs. It will be specially evaluated if the metal content tends to be higher in the dam area as observed by Mariani and Pompêo (2008) in Rio Grande reservoir and Pompêo et al. (2013) in Guarapiranga. The second objective was to determine the extent of the contamination, the bioavailability, and the ecological risk by applying several criteria such as comparison with regional backgrounds (RB) and by using international indexes: enrichment factors, pollution load indexes, and sediment quality guideline values. With this data, it will be possible to identify areas that require efforts to control contamination levels and assist the establishment of water resources monitoring and management programs.

\section{Materials and methods}

Study area

Surface sediments were sampled in seven reservoirs: Broa (sampled on June 11, 2015), Barra Bonita (June 18, 2015), Salto Grande (June 25, 2015), Itupararanga (September 10, 2015), Igaratá (September 24, 2015), Atibainha (October 1, 2015), and Rio Grande (Billings Complex) (October 8, 2015), all located in São Paulo State, Brazil (Fig. 1; Table 1).

The Barra Bonita, Salto Grande, and Itupararanga reservoirs can be characterized as being influenced by the presence of intense agricultural activities along their margins, as well as sewage inputs from urban areas (Buzelli and Cunha-Santino 2013; Fonseca and Matias 2014; Frascareli et al. 2015; Tundisi et al. 2015). The Salto Grande reservoir basin is influenced by a petrochemical complex that can negatively affect the water quality of this important water source, including contamination by metals (Leite et al. 2004). The Atibainha reservoir belongs to the Cantareira System, and the Rio Grande reservoir is located in the Billings Complex
(Mariani and Pompêo 2008), both in basins lacking adequate sewage treatment systems. The Broa reservoir (the smallest one) is impacted by inputs of untreated domestic sewage, resulting in high trophic levels (Tundisi et al. 2015). This reservoir has also been found to be affected by metals originating from fishing, boats, fuel use, and paint residues (Dornfeld et al. 2001).

The three sampling sites selected at each reservoir are shown in Fig. 1, where $\mathrm{R}$ indicates the main river water inlet area, $\mathrm{C}$ the central region, and $\mathrm{D}$ the dam region, according to the compartmentalization theory of Thornton et al. (1990).

\section{Sediment sampling}

At each sampling station, surface sediment $(4 \mathrm{~cm})$ was sampled three times with a $400 \mathrm{~cm}^{2}$ Lens type dredge. The sediments were stored in $100 \mathrm{~mL}$ plastic bottles that had been previously washed with $10 \%$ nitric acid. The bottles were kept in the dark in insulated bags. In the laboratory, the sediments were dried at $50{ }^{\circ} \mathrm{C}$ in a forced aeration oven and were then macerated using a glass mortar and pestle.

\section{Determination of metals}

The dry sediments were prepared according to Method 3050 B of US EPA series SW-846 (US EPA 1996) for the analysis of $\mathrm{Cd}, \mathrm{Cr}, \mathrm{Ni}, \mathrm{Pb}, \mathrm{Zn}$, and $\mathrm{Mn}$, as well as the conservative elements $\mathrm{Al}$ and $\mathrm{Fe}$. For samples with levels above background, analysis was made of metals weakly bound to the sediment, corresponding to the potentially bioavailable fraction (Mozeto et al. 2014; Cardoso-Silva et al. 2016b), following the procedure described by DePaula and Mozeto (2001). The metal analyses were performed by inductively coupled plasma-atomic emission spectroscopy (ICP-OES), using an Agilent Model 720 instrument. The background values were estimated based on the three bottommost mean concentrations of a core collected in the dam area of each reservoir. The data for this analysis correspond to of another study currently under development.

\section{Measurement of other sediment parameters}

Determination of organic matter was performed using the ignition method (Meguro 2000). The grain size was determined by mechanical separation of particles 

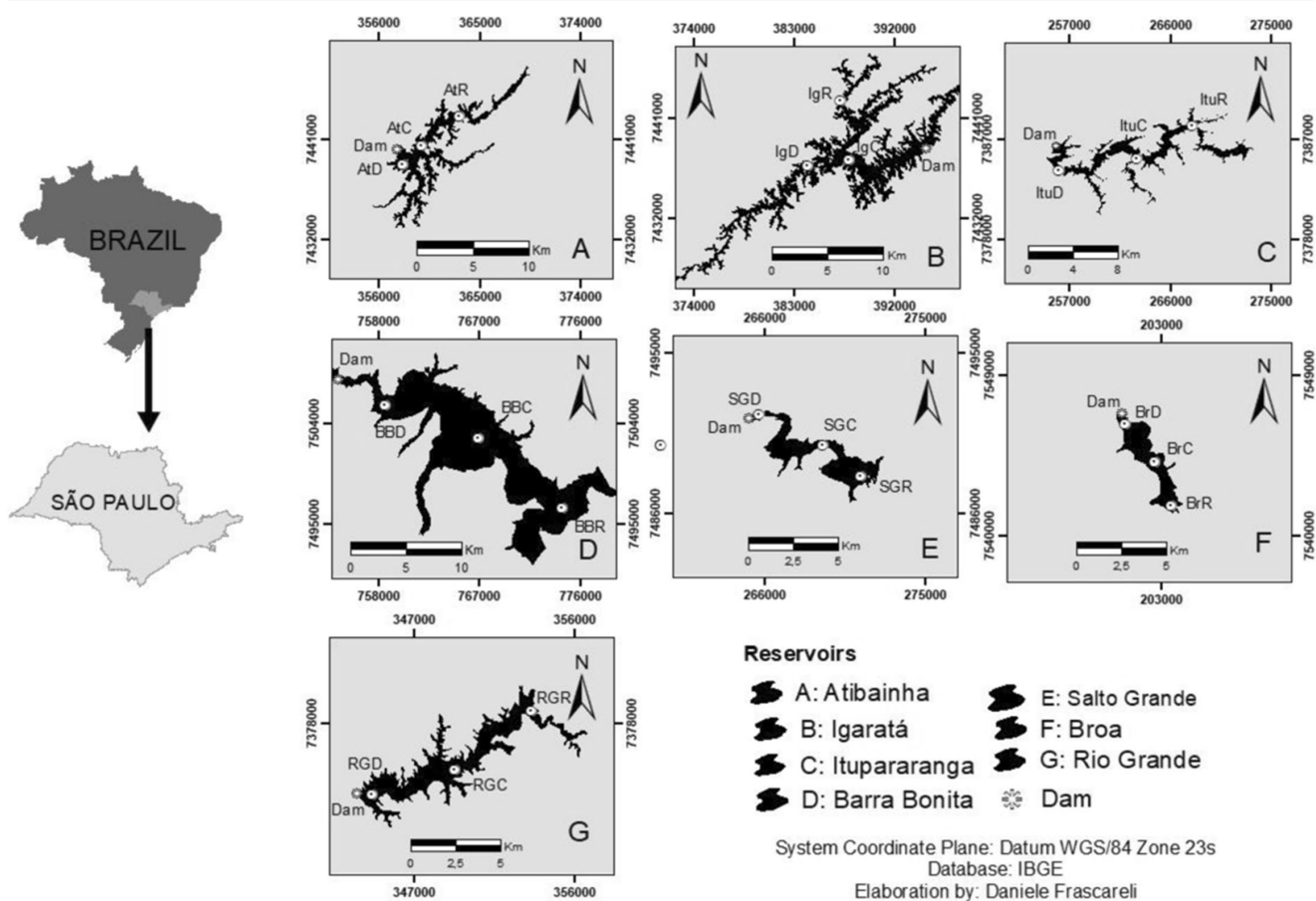

\section{Reservoirs}

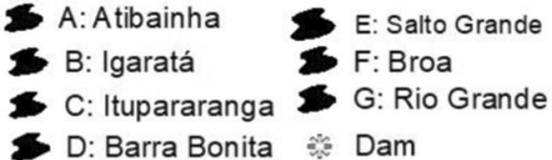

System Coordinate Plane: Datum WGS/84 Zone 23s Database: IBGE

\section{Elaboration by: Daniele Frascareli}

Fig. 1 Reservoirs analyzed in São Paulo State, Brazil. Sampling stations: Atibainha (AtR: river; AtC: center; AtD: dam), Igaratá (IgR: river; IgG: center; IgD: dam), Itupararanga (ItuR: river; ItuC: center; ItuD: dam), Barra Bonita (BBR: river; BBC: center; BBD:

dam), Broa (BrD, BrC, BrD), Salto Grande (SGR: river; SRC: center; SRD: dam), Rio Grande (RGR: river; RGC: center; RGD: dam)

larger than $2 \mathrm{~mm}$ by sieving (sieve no. 10 mesh ABNT) and subsequent sedimentation of particles smaller than $2 \mathrm{~mm}$ (sieve size opening $63 \mu \mathrm{m}, 230$ mesh ABNT) (Piper 1947, modified by Meguro 2000). Determination of the total phosphorus (TP) content in the sediment followed the Andersen

Table 1 Morphometric characteristics of the reservoirs studied

\begin{tabular}{|c|c|c|c|c|c|c|}
\hline & Year $^{\mathrm{a}}$ & $\begin{array}{l}\text { Area } \\
\left(\mathrm{km}^{2}\right)\end{array}$ & $\begin{array}{l}\text { Volume } \\
\left(\mathrm{m}^{3}\right)\end{array}$ & $\begin{array}{l}\text { Residence } \\
\text { time } \\
\text { (days) }\end{array}$ & $\begin{array}{l}\text { Mean } \\
\text { depth }(\mathrm{m})\end{array}$ & $\begin{array}{l}\text { Maximum } \\
\text { depth (m) }\end{array}$ \\
\hline Broa & 1936 & 5.8 & $2.2 \mathrm{E}+07$ & $20-40$ & 3 & 12 \\
\hline Barra Bonita & 1963 & 324.84 & $3.2 \mathrm{E}+09$ & 20 & 10.5 & 25 \\
\hline $\begin{array}{l}\text { Salto } \\
\text { Grande }\end{array}$ & 1949 & 11.5 & $1.1 \mathrm{E}+08$ & 30 & 8 & 19.8 \\
\hline Itupararanga & 1912 & 29.9 & $2.6 \mathrm{E}+08$ & 250 & 7.8 & - \\
\hline Rio Grande & 1981 & 7.4 & $1.1 \mathrm{E}+08$ & 228 & 26.2 & - \\
\hline Atibainha & 1975 & 20.09 & $9.5 \mathrm{E}+07$ & 105.8 & 4.8 & - \\
\hline Igaratá & 1969 & 60.5 & $1.4 \mathrm{E}+06$ & 306 & 14.2 & 68 \\
\hline
\end{tabular}

${ }^{\mathrm{a}}$ Construction year 
method (1976), as described by Pompêo and Moschini-Carlos (2003), with measurement of absorbance using a Micronal AJX-1900 spectrophotometer. Total nitrogen (TN) was determined by the method of digestion in concentrated sulfuric acid, followed by distillation with collection in boric acid (Eaton et al. 2005).

Analysis of the bottom water and trophic state of the column water

At each sampling station, the parameters measured in the bottom water included dissolved oxygen (DO), $\mathrm{pH}$, electrical conductivity (EC), temperature (Temp), and redox potential (ORP), using a multi-parameter probe (U52, Horiba). These analyses were performed in order to assess the possibility of metals being released into the water column.

The trophic state index (TSI) values were set according to the method of Carlson (1977), modified by Lamparelli (2004) for tropical and subtropical environments, using measurements of total phosphorus (TP) and chlorophyll-a (Cl-a). Cl-a was determined as described by Wetzel and Likens (1991). TP was measured using the method of Valderrama (1981). In the TSI calculation, the phosphorus and chlorophyll-a values were expressed in milligrams per liter. This analysis employed the integrated water column, which was collected using a plastic tube $2 \mathrm{~cm}$ in diameter (INAG 2009; Navarro et al. 2006; Becker et al. 2010). The integrated water column represented the depth of the photic zone, which was determined by multiplying the Secchi disk depth by 2.7 (Cole 1994; Huszar et al. 2000; Soares et al. 2008; Sevindik et al. 2017). Previous studies have linked the eutrophication of some of the studied reservoirs (Mariani and Pompêo 2008) to metals contamination, and the TSI is an important tool for evaluation of the allochthonous contribution of possible contaminants in the aquatic ecosystem.

Quantification of sediment pollution

\section{Sediment quality guideline values}

The empirical SQGs established by CCME (1999) were used to evaluate the toxic effects of the metals, considering the interim sediment quality guideline (ISQG)/ threshold effect level (TEL) and the probable effect level (PEL). When the metal concentration is less than the
TEL value, toxicity is unlikely to occur (i.e., fewer than $25 \%$ adverse effects occur below the TEL), while if the concentration is higher than the PEL, toxicity is likely to occur (i.e., more than $50 \%$ adverse effects occur above the PEL). For concentrations between the ISQG and the PEL, toxic effects are uncertain. Other data used were the regional background (RB) concentrations determined by sediment core analysis (Table 2).

\section{Enrichment factor}

Contamination by metals can be evaluated using enrichment factors to normalize the data, according to Eq. 1 (Sutherland 2000):

$$
\mathrm{EF}=\frac{\frac{M e}{E l}}{\frac{M e r}{E l r}},
$$

where $\mathrm{EF}$ is the enrichment factor, $\mathrm{Me} / \mathrm{El}$ is the ratio of the concentrations of the metal analyzed and the conservative element in the sample, and Mer/Elr is the ratio of the regional reference value for the analyzed metal and the value for the conservative element.

\section{Pollution load index}

The degree of pollution by metals in the sediment can be assessed using the PLI defined as the $n$th root of the multiplications of the contamination factor of metals (CF), calculated using Eq. 2 (Tomlinson et al. 1980):

$\mathrm{PLI}=(C F 1 \times C F 2 \times C F 3 \times \ldots . \times C F n)^{1 / n}$

where $\mathrm{CF}\left(=\mathrm{C}_{\text {metal }} / \mathrm{C}_{\text {background }}\right)$ is the ratio between the metal concentration in the sample and the regional background (RB) value (Table 2), and $n$ is the number of metals. Table 3 lists the index values and their attributions.

Statistical analysis

The spatial distribution and geochemistry of the metals were evaluated using principal component analysis (PCA) based on a correlation matrix (Legendre and Legendre 1998). The data were standardized by $z$-score, and the aluminum background for each reservoir was used for normalization (Table 2). The spatial heterogeneity of the reservoirs was assessed by analysis of 
Table 2 Mean concentrations (in $\mathrm{mg} \mathrm{kg}^{-1}$ ) for the bottommost three depths of the sediment cores for each reservoir, employed for normalization using background values

\begin{tabular}{lllllrrr}
\hline & $\mathrm{Cu}$ & $\mathrm{Cr}$ & $\mathrm{Ni}$ & $\mathrm{Pb}$ & $\mathrm{Zn}$ & $\mathrm{Mn}$ & $\mathrm{Al}$ \\
\hline $\mathrm{Br}$ & 32.20 & 25.44 & 12.67 & 15.06 & 42.27 & 118.41 & $54,668.86$ \\
$\mathrm{BB}$ & 51.10 & 34.12 & 40.60 & 18.53 & 78.28 & 2421.78 & $36,623.72$ \\
SG & 51.33 & 45.15 & 23.83 & 21.53 & 88.05 & 143.90 & $43,138.28$ \\
ITU & 18.64 & 30.88 & 7.15 & 24.53 & 39.80 & 583.65 & $42,183.02$ \\
IGA & 16.27 & 43.53 & 12.19 & 23.83 & 58.78 & 331.54 & $46,569.91$ \\
RG & 65.99 & 57.04 & 14.65 & 42.41 & 138.59 & 53.82 & $33,563.40$ \\
ATI & 23.89 & 33.40 & 10.92 & 21.89 & 52.26 & 300.53 & $46,197.90$ \\
\hline
\end{tabular}

similarity (two-way ANOSIM), employing correlation between distance matrices. A correlation table was also constructed using Spearman distances among the data for particle size, OM, and nutrients in the sediment and water, for all the reservoirs studied, in order to identify significant correlations $(\rho>0.7)$ of the variables. The software packages used were PAST 2.7 (Hammer et al. 2001) and R (Oksanen et al. 2011).

\section{Results and discussion}

The existence of spatial heterogeneity in the surface sediments was evident between sample points and between the seven analyzed reservoirs, with the formation of a gradient along the reservoir for some variables and reservoirs. The heterogeneity was evidenced by the statistical analyses, both the basic descriptive and the multivariate analyses.

Sediment characterization

In all the reservoirs studied, the sediment particle size distribution was dominated by the fine grain size siltclay fraction $(<63 \mu \mathrm{m})$. The contribution of this fraction

Table 3 Enrichment factor (EF) (Sutherland 2000) and pollution load index (PLI) (Tomlinson et al. 1980) classifications

\begin{tabular}{llll}
\hline EF value & Enrichment & PLI value & Contamination \\
\hline$<2$ & Absent/very low & PLI $>1$ & Present \\
$2 \leq \mathrm{EF}<5$ & Moderate & PLI $<1$ & Absent \\
$5 \leq \mathrm{EF}<20$ & Considerable & & \\
$20 \leq \mathrm{EF}<40$ & High & & \\
$>40$ & Very high & & \\
\hline
\end{tabular}

increased from upstream to downstream in the Broa, Salto Grande, Rio Grande, and Barra Bonita reservoirs. Souza and Wasserman (2015) found that predominance of fine fractions indicatives a low-energy environment and was associated with the preservation of organic matter. The OM contents of the sediments exceeded $10 \%$ for all the reservoirs, with the highest average levels observed in the Broa $(28 \pm 0.99 \%)$ and Barra Bonita $(24 \pm 2.72 \%)$ reservoirs, where concentrations exceeded $30 \%$ in the dam areas (Table 4 ).

The organic loads that enter the reservoirs can lead to high concentrations of nutrients in sediments (Burger et al. 2007; Li et al. 2016). Spearman test (with data for all the reservoirs) showed positive correlations $(\rho>0.7)$ between the phosphorus concentrations in the water and the sediments $(\rho=0.81)$, as well as between the concentration of phosphorus in the sediment and the trophic state of the water column $(\rho=0.72)$. These results suggested that the flow of nutrients from the sediments represents a significant fraction of the requirement for primary production in the water column (Søndergaard et al. 1999). The trophic conditions of the reservoirs ranged from hypereutrophic to oligotrophic, with the Salto Grande and Barra Bonita reservoirs classified as hypereutrophic. Although the Broa reservoir is considered oligomesotrophic most of the time (Tundisi et al. 2015), in this work, the reservoir was showed as supereutrophy. The Rio Grande and Itupararanga reservoirs were classified as eutrophic, while the Igaratá and Atibainha reservoirs were oligotrophic (Table 4). The trophic state therefore followed the order: Salto Grande $>$ Broa $>$ Barra Bonita $>$ Rio Grande $=$ Itupararanga $>$ Igaratá = Atibainha.

According to the Ontario Sediment Quality Guidelines ( $\mathrm{SQG}$ ), the concentrations of TP in the Barra Bonita reservoir sediment could be considered high, 
Table 4 Sediment and water column characteristics. $\overline{\mathrm{x}}$ : mean value; SD: standard deviation; CV: coefficient of variation; OM: organic matter; TP: total phosphorus; TN: total nitrogen; Cl-a: chlorophyll-a; TP-water: total phosphorus in water; TSI: tropic state index.

\begin{tabular}{|c|c|c|c|c|c|c|c|c|c|c|}
\hline & Units & $\begin{array}{l}\mathrm{OM} \\
\%\end{array}$ & $\begin{array}{l}\mathrm{TP} \\
\mathrm{g} \mathrm{kg}^{-1}\end{array}$ & $\begin{array}{l}\mathrm{TN} \\
\mathrm{g} \mathrm{kg}^{-1}\end{array}$ & $\begin{array}{l}\text { Clay } \\
\text { G }\end{array}$ & $\begin{array}{l}\text { Silt } \\
\mathrm{g}\end{array}$ & $\begin{array}{l}\text { Sand } \\
\mathrm{g}\end{array}$ & $\begin{array}{l}\mathrm{Cl}-\mathrm{a} \\
\mu \mathrm{g} \mathrm{L}{ }^{-1}\end{array}$ & $\begin{array}{l}\text { TP-water } \\
\mu \mathrm{g} \mathrm{L} \mathrm{L}^{-1}\end{array}$ & TSI \\
\hline \multirow[t]{3}{*}{$\mathrm{Br}$} & $\overline{\mathrm{x}}$ & 28.92 & 1.25 & 5.06 & 1.08 & 7.76 & 0.39 & 19.95 & 25.19 & 67.53 \\
\hline & SD & 0.99 & 0.10 & 1.58 & 0.32 & 1.52 & 1.16 & 4.52 & 4.29 & 0.98 \\
\hline & $\mathrm{CV}$ & 3.41 & 7.67 & 31.18 & 29.68 & 19.53 & 3.01 & 0.23 & 0.17 & 0.01 \\
\hline \multirow[t]{3}{*}{ BB } & $\overline{\mathrm{x}}$ & 24.92 & 3.72 & 4.25 & 2.65 & 5.69 & 0.10 & 10.34 & 76.96 & 65.00 \\
\hline & SD & 2.72 & 0.24 & 2.12 & 0.18 & 2.45 & 0.03 & 4.40 & 12.13 & 1.54 \\
\hline & $\mathrm{CV}$ & 10.90 & 6.41 & 49.78 & 6.94 & 43.01 & 0.35 & 0.43 & 0.16 & 0.02 \\
\hline \multirow[t]{3}{*}{ SG } & $\overline{\mathrm{x}}$ & 15.65 & 1.85 & 0.41 & 2.56 & 7.83 & 0.05 & 19.95 & 94.87 & 63.52 \\
\hline & SD & 1.86 & 0.10 & 0.24 & 0.36 & 0.57 & 0.03 & 4.52 & 17.16 & 1.11 \\
\hline & $\mathrm{CV}$ & 11.90 & 5.66 & 58.54 & 13.85 & 7.23 & 0.57 & 0.23 & 0.18 & 0.02 \\
\hline \multirow[t]{3}{*}{ ITU } & $\overline{\mathrm{x}}$ & 14.91 & 0.64 & 3.15 & 2.37 & 8.35 & 0.16 & 7.97 & 19.03 & 55.42 \\
\hline & SD & 1.28 & 0.12 & 0.56 & 0.48 & 0.69 & 0.05 & 1.75 & 6.53 & 1.61 \\
\hline & $\mathrm{CV}$ & 8.58 & 18.49 & 17.75 & 20.13 & 8.25 & 0.32 & 0.22 & 0.34 & 0.03 \\
\hline \multirow[t]{3}{*}{ IGA } & $\overline{\mathrm{x}}$ & 14.36 & 1.16 & 1.87 & 3.12 & 6.88 & 0.61 & 1.56 & 11.75 & 60.31 \\
\hline & SD & 1.49 & 0.13 & 0.22 & 0.56 & 0.95 & 0.17 & 1.37 & 3.73 & 1.18 \\
\hline & $\mathrm{CV}$ & 10.36 & 11.22 & 11.58 & 17.97 & 13.74 & 0.28 & 0.88 & 0.32 & 0.02 \\
\hline \multirow[t]{3}{*}{ ATI } & $\overline{\mathrm{x}}$ & 19.28 & 0.37 & 1.66 & 2.88 & 7.49 & 0.02 & 5.11 & 8.12 & 56.08 \\
\hline & SD & 1.63 & 0.01 & 0.33 & 0.29 & 0.53 & 0.09 & 1.96 & 3.54 & 3.01 \\
\hline & $\mathrm{CV}$ & 8.45 & 2.36 & 20.08 & 10.10 & 7.08 & 4.41 & 0.38 & 0.44 & 0.05 \\
\hline \multirow[t]{3}{*}{$\mathrm{RG}$} & $\overline{\mathrm{x}}$ & 14.04 & 1.21 & 4.75 & 2.09 & 7.87 & 0.34 & 6.69 & 21.55 & 60.01 \\
\hline & $\mathrm{SD}$ & 1.92 & 0.12 & 1.79 & 0.56 & 0.58 & 0.12 & 2.07 & 8.21 & 0.82 \\
\hline & $\mathrm{CV}$ & 13.67 & 10.29 & 37.68 & 26.84 & 7.36 & 0.34 & 0.31 & 0.38 & 0.01 \\
\hline
\end{tabular}

with concentrations above $2 \mathrm{~g} \mathrm{~kg}^{-1}$ (mean of 3.72 $\pm 0.24 \mathrm{~g} \mathrm{~kg}^{-1}$ ) and possible severe effects on sediment-dwelling organisms. The other reservoirs presented lower concentrations ( $\mathrm{TP}>0.6 \mathrm{~g} \mathrm{~kg}^{-1}$ ), with the exceptions of the Itupararanga reservoir (dam area) and the Atibainha reservoir (all areas), where the values were below $0.6 \mathrm{~g} \mathrm{~kg}^{-1}$. For TN, the Broa, Barra Bonita, and Rio Grande reservoirs presented concentrations above $4.8 \mathrm{~g} \mathrm{~kg}^{-1}$, indicating possible severe effects. The other reservoirs mostly presented concentrations between 0.5 and $4.8 \mathrm{~g} \mathrm{~kg}^{-1}$, indicating lower effects, while values below $0.5 \mathrm{~g} \mathrm{~kg}^{-1}$ were found for the transitional and dam areas of the Salto Grande reservoir.

In the Itupararanga and Broa reservoirs, the nutrients (TN and TP) showed the highest levels upstream, indicating significant pollution sources upstream of these reservoirs, as expected for reservoirs with anthropic influence or waste water inputs (Kimmel et al. 1990). The same trend was found for TN in the Barra Bonita, Igaratá, and Salto Grande reservoirs and for TP in the
Rio Grande reservoir. Increasing horizontal concentrations of TN in the Rio Grande and Atibainha reservoirs, and TP in the Barra Bonita and Igaratá reservoirs, might have been due to the surrounding activities in the watersheds of these reservoirs.

Metals

The comparison of metal concentrations with background reference values can be used to indicate the degree of metal enrichment (Zahra et al. 2014). In the present work, enrichment associated with anthropogenic activities was observed, with values above background for $\mathrm{Cu}$ in the Rio Grande $\left(2914.08 \pm 1704.52 \mathrm{mg} \mathrm{kg}^{-1}\right)$, $\mathrm{Zn}$ in the Salto Grande $\left(102.5 \pm 38.06 \mathrm{mg} \mathrm{kg}^{-1}\right)$, and Barra Bonita $\left(101.63 \pm 100.92 \mathrm{mg} \mathrm{kg}^{-1}\right)$ reservoirs, as well as $\mathrm{Ni}$ in the Barra Bonita $\left(72.88 \pm 71.86 \mathrm{mg} \mathrm{kg}^{-1}\right)$ and Rio Grande $\left(18.91 \pm 3.33 \mathrm{mg} \mathrm{kg}^{-1}\right)$ reservoirs (Tables 2 and 5). 
Table 5 Concentrations of metals $\left(\mathrm{mg} \mathrm{kg}^{-1}\right)$ in the reservoir sediments. $\bar{x}$ : mean value, SD: standard deviation; CV: coefficient of variation

\begin{tabular}{|c|c|c|c|c|c|c|c|c|c|}
\hline & & $\mathrm{Al}$ & $\mathrm{Fe}$ & $\mathrm{Cu}$ & $\mathrm{Cr}$ & $\mathrm{Ni}$ & $\mathrm{Pb}$ & $\mathrm{Zn}$ & $\mathrm{Mn}$ \\
\hline \multirow[t]{3}{*}{$\mathrm{Br}$} & $\overline{\mathrm{x}}$ & $35,978.30$ & $35,238.97$ & 29.52 & 26.42 & 9.29 & 12.68 & 36.86 & 193.10 \\
\hline & SD & 4245.03 & 7674.37 & 1.44 & 4.72 & 0.51 & 1.06 & 6.15 & 23.79 \\
\hline & $\mathrm{CV}$ & 11.80 & 21.78 & 4.89 & 17.88 & 5.53 & 8.38 & 16.69 & 12.32 \\
\hline \multirow[t]{3}{*}{$\mathrm{BB}$} & $\overline{\mathrm{x}}$ & $39,950.15$ & $60,758.80$ & 44.68 & 36.93 & 72.88 & 15.87 & 101.63 & 2820.08 \\
\hline & SD & $38,770.20$ & $43,302.09$ & 43.88 & 36.10 & 71.86 & 13.35 & 100.92 & 2819.26 \\
\hline & $\mathrm{CV}$ & 4206.66 & 3491.09 & 7.27 & 3.19 & 7.02 & 2.17 & 10.79 & 385.11 \\
\hline \multirow[t]{3}{*}{$\mathrm{SG}$} & $\overline{\mathrm{x}}$ & $43,543.32$ & $38,269.16$ & 52.28 & 43.41 & 19.74 & 16.96 & 102.50 & 280.07 \\
\hline & SD & 5690.20 & 5905.11 & 13.01 & 8.60 & 4.00 & 2.45 & 38.06 & 78.02 \\
\hline & $\mathrm{CV}$ & 13.07 & 15.43 & 24.89 & 19.81 & 20.28 & 14.46 & 37.13 & 27.86 \\
\hline \multirow[t]{3}{*}{ ITU } & $\overline{\mathrm{x}}$ & $46,164.56$ & $50,118.51$ & 20.90 & 36.17 & 7.82 & 16.87 & 33.24 & 327.19 \\
\hline & SD & 946.33 & 3624.11 & 1.51 & 1.67 & 0.95 & 1.01 & 1.28 & 129.44 \\
\hline & $\mathrm{CV}$ & 2.05 & 7.23 & 7.21 & 4.61 & 12.13 & 6.00 & 3.86 & 39.56 \\
\hline \multirow[t]{3}{*}{ IGA } & $\overline{\mathrm{x}}$ & $53,922.49$ & $57,160.08$ & 16.51 & 47.23 & 11.44 & 28.15 & 54.79 & 200.13 \\
\hline & $\mathrm{SD}$ & 4070.49 & 7830.08 & 1.38 & 2.28 & 1.56 & 4.48 & 4.47 & 88.99 \\
\hline & $\mathrm{CV}$ & 7.55 & 13.70 & 8.37 & 4.84 & 13.68 & 15.91 & 8.16 & 44.47 \\
\hline \multirow[t]{3}{*}{ ATI } & $\overline{\mathrm{x}}$ & $45,978.79$ & $44,630.59$ & 21.79 & 39.46 & 10.72 & 20.61 & 49.37 & 388.01 \\
\hline & SD & 4177.58 & 6541.43 & 4.75 & 5.87 & 1.45 & 2.41 & 11.19 & 254.95 \\
\hline & $\mathrm{CV}$ & 9.09 & 14.66 & 21.81 & 14.87 & 13.49 & 11.71 & 22.66 & 65.71 \\
\hline \multirow[t]{3}{*}{$\mathrm{RG}$} & $\overline{\mathrm{x}}$ & $35,417.72$ & $59,821.36$ & 2914.08 & 46.37 & 18.91 & 32.85 & 128.22 & 530.29 \\
\hline & SD & 1044.34 & 4562.61 & 1704.52 & 2.96 & 3.33 & 4.25 & 26.49 & 249.59 \\
\hline & $\mathrm{CV}$ & 2.95 & 7.63 & 58.49 & 6.38 & 17.61 & 12.93 & 20.66 & 47.07 \\
\hline TEL $^{\mathrm{a}}$ & & - & - & 35.7 & 37.3 & 18 & 35 & 123 & - \\
\hline $\mathrm{PEL}^{\mathrm{a}}$ & & - & - & 197 & 90 & 36 & 91.5 & 315 & - \\
\hline
\end{tabular}

${ }^{a}$ CCME (1999)

The highest concentrations were found for $\mathrm{Al}$ and $\mathrm{Fe}$, due to the natural levels found in the clay minerals of these sediments (Landajo et al. 2004).

The Rio Grande reservoir (in the Billings Complex) showed the highest levels of $\mathrm{Cu}$, which were approximately 58-fold higher than the RB (Table 2), on average, with some sample stations showing values 100 -fold higher (Table 5) than the background value. The concentration of $\mathrm{Cu}$ increased from upstream to downstream, with the highest value in the dam area. The Rio Grande reservoir is located in an extremely urbanized area and is impacted by the dumping of domestic waste. Recent studies have investigated eutrophication and water management in this reservoir (Wengrat et al. 2011; Cardoso-Silva et al. 2014). In order to control phytoplankton growth, the company responsible for the public water supply in São Paulo State (SABESP) has employed algicides such as copper sulfate and hydrogen peroxide (Moschini-Carlos et al. 2009; Pompêo et al. 2015a, b). As a result, there is an accumulation of $\mathrm{Cu}$ in the sediment, especially in the dam area, where water is extracted for the public water supply. This preventive management is more intense in this region, since eutrophication can result in blooms of potentially toxic cyanobacteria (Wetzel 2001; Beghelli et al. 2016).

There are three main processes that control the level of copper in the water column, namely complexation, precipitation, and adsorption (Flemming and Trevors 1989), with action of a variety of ligands (hydroxyl and carbonate ions; nitrogen species; phosphates; organic matter; $\mathrm{Fe}, \mathrm{Mn}$, and $\mathrm{Al}$ hydrous oxides; sulfides; clay minerals) (Chapman et al. 1999; US EPA 2005; Díez et al. 2017). The speciation and solubility of $\mathrm{Cu}$ is dependent mainly on organic matter, $\mathrm{pH}$, and $\mathrm{Eh}$ (Sauvé et al. 1996). Under anaerobic conditions, $\mathrm{Cu}$ is reduced and forms highly stable complexes with sulfides (Di Toro et al. 1990). In the case of the Rio Grande reservoir, despite the high levels of metals (especially 
$\mathrm{Cu}$ ), Mariani and Pompêo (2008) observed high levels of sulfide and found that the metals were not bioavailable. However, a concern is that the Rio Grande reservoir presents the characteristics of a shallow and polymictic reservoir (Mariani and Pompêo 2008), and these conditions can lead to the transfer of oxygen to the bottom water and remobilization of metals to the water column. Therefore, the monitoring of levels of metals in both the water column and the sediment is important for maintenance of environment quality.

The Salto Grande reservoir showed higher metal concentrations in the upstream reservoir zone. The existence of urban areas, intense livestock grazing, production of sugarcane and citrus, and mining (Fonseca and Matias 2014) has led to a reduction in water quality due to the eutrophication process (Tundisi et al. 2015), together with the accumulation of toxic components in the sediment. These anthropic impacts in the Salto Grande watershed, and consequently in the reservoir, are of concern and are exacerbated by the activities of a petrochemical complex located upstream of the reservoir (Dornfeld et al. 2005). The effluents discharged into the Atibaia River, the main tributary of the Salto Grande reservoir, lead to high concentrations of metals in both the sediment and the water (Leite et al. 2004). The National Sanitation Information System (SNIS) provides data for the year 2014 concerning the collection and treatment of sewage from the city of Americana. Although $94.68 \%$ of the sewage collected was treated, only $50 \%$ of the total sewage was collected in the municipality (SNIS 2016), suggesting that $50 \%$ of the total sewage remained untreated and could have been discharged in natura into water bodies. The results for the upstream region indicated high concentrations of metals that were likely to have been originated from industrial activities along the Atibaia River as well as operational deficiencies in the sewage collection system.

The Barra Bonita reservoir is characterized by intense agricultural activity along the margins, especially sugarcane monoculture. This, coupled with the absence of riparian vegetation, contributes to the leaching of metals derived from pesticides and fertilizers used on crops. In addition, the Barra Bonita reservoir is located downstream of the highly industrialized and urbanized Piracicaba river basin, which contributes to the enrichment of the reservoir with metals (Rodgher et al. 2005; Smith and Espindola 2014) as well as nutrients (Belluta et al. 2016). The Barra Bonita reservoir showed levels increasing in the upstream-downstream direction for $\mathrm{Cu}$, $\mathrm{Ni}, \mathrm{Mn}$, and $\mathrm{Fe}$, while concentrations decreasing in the upstream-downstream direction were observed for $\mathrm{Cr}$, $\mathrm{Zn}$, and $\mathrm{Pb}$. The metals $\mathrm{Cr}, \mathrm{Zn}$, and $\mathrm{Ni}$ have been associated with landfill activities in the region (Sisinno and Moreira 1996), while $\mathrm{Pb}$ is present in certain dyes. The high concentrations of metals found in the Barra Bonita reservoir could therefore be attributed to the upstream activities associated with multiple land uses; beside, poor sewage treatment also contributes to the decreased environmental quality of the surface sediments.

Enrichment factors, pollution load indexes, sediment quality guidelines, and bioavailability of the metals

The EF values indicated considerable enrichment of $\mathrm{Cu}$ in the entrance area of the Rio Grande reservoir, high enrichment in the transitional region, and very high enrichment in the dam area (Table 6). The elements Ni and Mn showed moderate enrichment in the transitional and dam areas. The PLI values increased in the direction of water flow, probably due to the strong influence of $\mathrm{Cu}$.

The EF values for the Barra Bonita reservoir indicated depletion or very low enrichment of $\mathrm{Ni}$ in the dam area. The EF values for $\mathrm{Mn}$ in the Broa, Salto Grande, and Atibainha reservoirs were indicative of depletion or very low enrichment in the dam area (Table 6). These reservoirs, with the exception of the Atibainha reservoir, showed increases in line with the anthropic activities, in agreement with the results of the descriptive statistics and the background values ("Metals" section).

Although the concentrations of some metals were above the background in the Atibainha reservoir, the EF and PLI values did not indicate significant enrichment, except in the case of $\mathrm{Mn}$, for which the EF was considered moderate (Table 6). There are no historical records for metal contamination in this reservoir.

Enrichment of metals in the Rio Grande and Barra Bonita reservoirs followed horizontal trends, with high concentrations in the dam regions, where the metals accumulated due to the intrinsic hydrological and morphological characteristics of these regions, including a predominance of smaller particles (clay), presence of OM (Mariani and Pompêo 2008; Pompêo et al. 2013; Cardoso-Silva et al. 2016a), and slower water velocity (Wei et al. 2009). These characteristics are expected for 
Table 6 EF and PLI values for the Broa, Atibainha, Salto Grande, Itupararanga, Igaratá, Barra Bonita, and Rio Grande reservoirs

\begin{tabular}{|c|c|c|c|c|c|c|c|}
\hline \multirow[b]{2}{*}{ Abbreviations } & \multicolumn{6}{|l|}{$\mathrm{EF}$} & \multirow[t]{2}{*}{ PLI } \\
\hline & $\mathrm{Cu}$ & $\mathrm{Cr}$ & $\mathrm{Ni}$ & $\mathrm{Pb}$ & $\mathrm{Zn}$ & $\mathrm{Mn}$ & \\
\hline BrR & 1.52 & 2.26 & 0.66 & 1.47 & 1.91 & 3.28 & 0.24 \\
\hline $\mathrm{BrC}$ & 1.34 & 1.58 & 0.56 & 1.40 & 1.20 & 2.41 & 0.13 \\
\hline $\mathrm{BrD}$ & 1.19 & 1.06 & 0.47 & 1.03 & 0.99 & 1.93 & 0.07 \\
\hline ATIR & 0.63 & 1.02 & 1.22 & 0.95 & 1.31 & 2.65 & 0.48 \\
\hline ATIC & 0.95 & 0.86 & 0.85 & 0.97 & 0.72 & 0.48 & 0.11 \\
\hline ATID & 1.18 & 0.78 & 0.91 & 0.91 & 0.85 & 0.87 & 0.06 \\
\hline SGR & 1.23 & 1.10 & 0.95 & 0.82 & 1.62 & 2.16 & 2.83 \\
\hline SGC & 0.86 & 0.89 & 0.75 & 0.78 & 0.93 & 2.09 & 0.31 \\
\hline SGD & 0.92 & 0.88 & 0.79 & 0.78 & 0.87 & 1.56 & 0.13 \\
\hline ItuR & 0.90 & 1.08 & 0.90 & 0.58 & 0.76 & 0.21 & 0.00 \\
\hline ItuC & 1.13 & 1.05 & 0.93 & 0.63 & 0.79 & 0.73 & 0.00 \\
\hline ItuD & 1.05 & 0.99 & 0.71 & 0.63 & 0.75 & 0.66 & 0.00 \\
\hline IGAR & 0.70 & 0.82 & 0.60 & 0.79 & 0.69 & 0.78 & 0.12 \\
\hline IGAC & 0.98 & 1.00 & 0.70 & 1.29 & 0.79 & 0.38 & 0.12 \\
\hline IGAD & 1.71 & 0.78 & 0.74 & 0.79 & 0.75 & 0.80 & 0.07 \\
\hline BBR & 0.68 & 1.01 & 1.51 & 0.76 & 1.27 & 1.00 & 0.29 \\
\hline $\mathrm{BBC}$ & 0.63 & 0.91 & 1.49 & 0.65 & 1.16 & 1.03 & 0.32 \\
\hline BBD & 1.20 & 1.01 & 1.96 & 0.61 & 1.22 & 1.32 & 0.19 \\
\hline RGR & 12.09 & 0.76 & 1.79 & 0.76 & 1.12 & 1.50 & 3.09 \\
\hline RGC & 37.18 & 0.71 & 2.12 & 0.60 & 0.71 & 2.22 & 6.22 \\
\hline RGD & 77.78 & 0.85 & 2.90 & 0.84 & 0.79 & 5.03 & 70.68 \\
\hline
\end{tabular}

For abbreviations, see the legend of Fig. 1

an artificial environment in which particles tend to precipitate out in the direction of the water flow.

Despite the evidence of enrichment, observed through ISQG/TEL and PEL values, toxicity was only likely to be associated with $\mathrm{Cu}$ in the Rio Grande reservoir and Ni in the Barra Bonita reservoir. The Salto Grande reservoir showed possible toxicity of $\mathrm{Cu}$ (Table 7).

The toxicity levels should be considered in light of the physical and chemical characteristics of the environments that might favor the retention of metals in sediments. The DO values for the bottom water of the sampled areas were $1.68 \pm 0.36 \mathrm{mg} \mathrm{L}^{-1}$ (Barra Bonita), $1.03 \pm 0.23 \mathrm{mg} \mathrm{L}^{-1}$ (Rio Grande), and $2.30 \pm$ $0.25 \mathrm{mg} \mathrm{L}^{-1}$ (Salto Grande). The presence of high loads of organic material and the predominantly fine particle size of the surface sediments provided a reducing environment favorable for metal immobilization (Jain et al. 2007). Such conditions can lead to the formation of
Table 7 Average concentrations of $\mathrm{Cu}, \mathrm{Ni}$, and $\mathrm{Zn}$ in the Barra Bonita (BB), Salto Grande (SG), and Rio Grande (RG) reservoirs and comparison with threshold effect level (TEL), probable effect level (PEL), and background (BG) values

\begin{tabular}{lccc}
\hline & $\mathrm{Cu}$ & $\mathrm{Ni}$ & $\mathrm{Zn}$ \\
\hline BB & 16.73 & $36.20^{\mathrm{b}}$ & 64.25 \\
SG & $39.49^{\mathrm{a}}$ & 4.72 & 90.84 \\
RG & $1404.83^{\mathrm{b}}$ & 4.80 & 74.44 \\
TEL & 35.7 & 18 & 123 \\
PEL & 197 & 36 & 315 \\
\hline
\end{tabular}

${ }^{\mathrm{a}}$ Between TEL and PEL

${ }^{\mathrm{b}}$ Above PEL

sulfides, which then reduce iron and manganese oxides to highly insoluble forms, in combination with other metals (Di Toro et al. 1990; Fagnani et al. 2011). Mariani and Pompêo (2008) found that sulfides were responsible for controlling the bioavailability of metals in sediments of the Rio Grande reservoir, and although this reservoir contained high concentrations of metals, the presence of sulfides could help to maintain them in insoluble forms unavailable to biota. Besides the high levels of sulfides, the authors also observed elevated levels of organic matter and high $\mathrm{pH}$.

Spatial heterogeneity between and within reservoirs

The spatial heterogeneity among the reservoirs was investigated using PCA (Fig. 2). Based on the eigenvalues, two principal components (PCs) explained $57.38 \%$ of the total variance. PC 1 explained $30.2 \%$ of the variance and was mainly influenced by the variables $\mathrm{Al}$ (0.79), Fe (0.84), Cr (0.87), Pb (0.84), OM (-0.76), and Chl_water $(-0.78)$. The variables $\mathrm{OM}$ and Chl-a were positively correlated to PC 1 and influenced the position of the Broa reservoir in the PCA map. The variables $\mathrm{Cr}$ (0.87), $\mathrm{Fe}(0.84), \mathrm{Pb}(0.84), \mathrm{Cu}(0.53)$, and Clay (0.52) were negatively associated with PC 1 and determined the PCA map position of the Rio Grande reservoir, which showed significant signs of metal contamination.

PC 2 explained $27.5 \%$ of the total variance and was mainly influenced by the variables $\mathrm{Ni}(0.86), \mathrm{Mn}(0.81)$, TP (0.91), TP water (0.87), EC bot (0.81), and TN water (0.72), reflecting the higher trophic levels in the Salto Grande and Barra Bonita reservoirs. These reservoirs were also influenced by the variables EC, DO, and Temp (bottom water); TP and Chl-a (water column); 


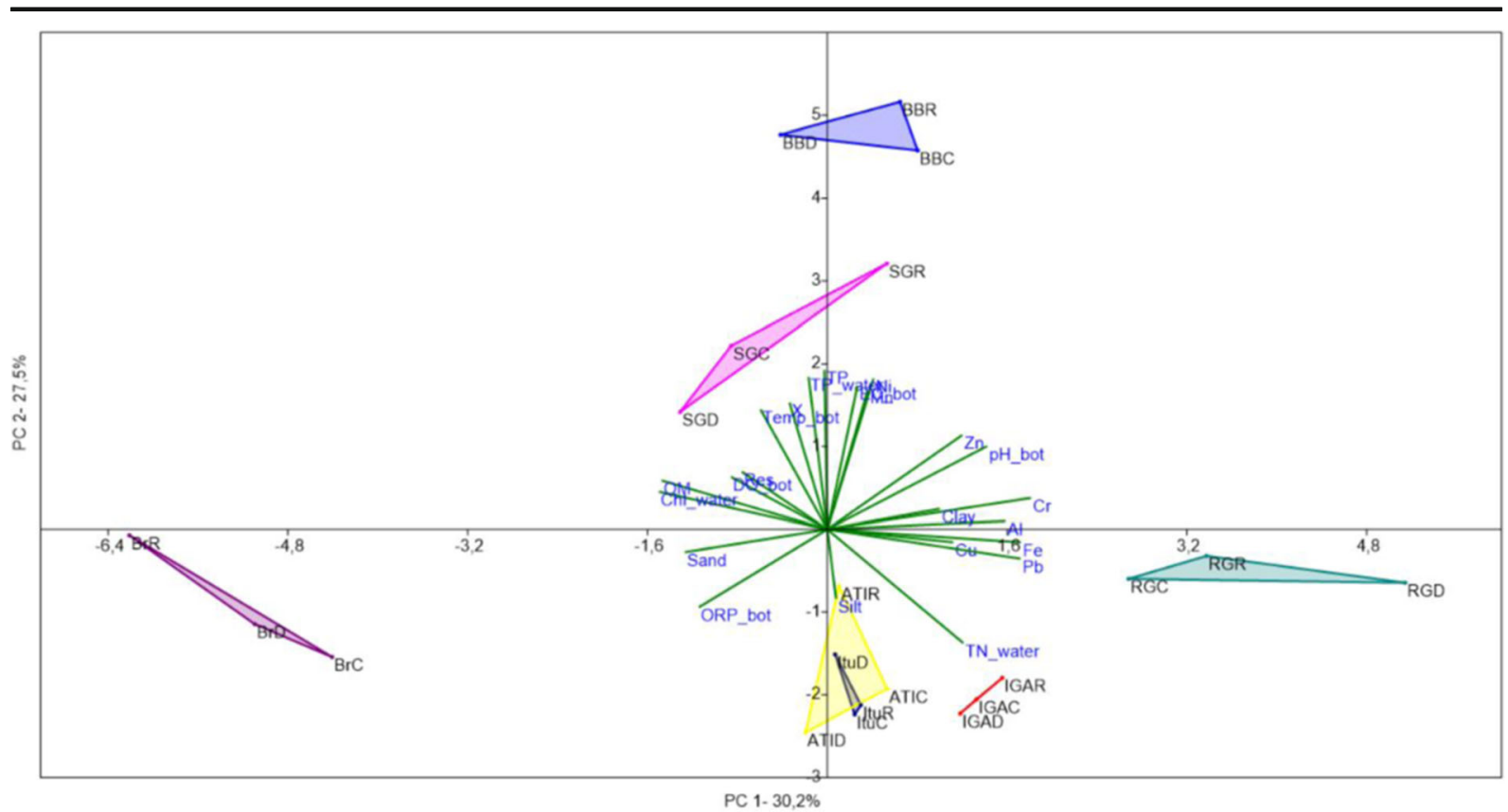

Fig. 2 PCA results using data for residence time; metals, nutrients, granulometry, and OM (sediment); nutrients, ORP, pH, and DO (bottom water); and TP and chlorophyll (water column)

and TP (sediment). They showed the highest levels of EC $\left(374 \pm 26\right.$ and $\left.279 \pm 2.4 \mu \mathrm{S} \mathrm{cm} \mathrm{cm}^{-1}\right)$, low levels of oxygenation (DO values of $2.3 \pm 0.25$ and $1.68 \pm$ $\left.0.36 \mathrm{mg} \mathrm{L}^{-1}\right)$, slightly basic $\mathrm{pH}(6.77 \pm 0.11$ and 6.84 \pm 0.11 ), and temperatures of $21.75 \pm 0.2$ and $20.95 \pm$ $0.14{ }^{\circ} \mathrm{C}$, respectively.

The Atibainha, Igaratá, and Itupararanga reservoirs were positively associated with PC 1 and negatively associated with PC 2. These reservoirs also presented low oxygenation levels and were the deepest (order of depth: Igaratá > Atibainha > Rio Grande > Itupararanga). The low oxygen values could have been due to the effects of depth and stratification processes. These reservoirs also showed slightly basic $\mathrm{pH}$, the lowest $\mathrm{EC}$ values (Atibainha 46 \pm 1.4 ; Igaratá 44.33 \pm 17.11 ; Rio Grande $107 \pm 1.22$; Itupararanga $81.67 \pm 1.56 \mu \mathrm{S} \mathrm{cm}^{-1}$ ), and the longest residence times.

In summary, the PCA results evidenced the heterogeneity between reservoirs; it indicated the existence of four groups of reservoirs, as follows: (group 1) Salto Grande and Barra Bonita; (group 2) Broa; (group 3) Igaratá, Itupararanga, and Atibainha; and (group 4) Rio Grande. These groups highlighted the differences among the reservoirs in terms of morphology and impacts and were created as a function of the variables residence time, nutrients in water and sediment, granulometry, $\mathrm{OM}$ in sediment, and $\mathrm{DO}$, ORP, and $\mathrm{pH}$ of the bottom water. The reservoirs with greater depth and longer residence times were in groups 3 and 4, while those with shallower depth and shorter residence times were in groups 1 and 2 . The metal concentrations and eutrophication also contributed to the formation of groups, notably group 4 (metals) and groups 1 and 2 (nutrients). Group 3 was least impacted by metals and nutrients.

For metals in sediments, the spatial distribution followed different patterns between the points and the metals in the different reservoirs. Based on the data of normalized metals through the enrichment factor (Table 6) and through linear regressions with these data (supplementary material), it is observed that in general the Broa reservoir presented higher enrichment factors for metals in the fluvial area as well as the Atibainha and Salto Grande reservoir for $\mathrm{Cr}, \mathrm{Ni}, \mathrm{Zn}$, and $\mathrm{Mn}$ and in Salto Grande also for $\mathrm{Cu}$. These variations were possibly associated to the operating regime of these reservoirs, promoting the sedimentation of these elements before reaching the dam. In these reservoirs, on the other hand, the highest nutrients and organic matter concentrations were observed in the dam area as a condition previous described by Thornton et al. (1990). 
In Rio Grande reservoir, an upstream-downstream gradient was observed and the highest concentrations of metals, nutrients, and $\mathrm{OM}$ in the sediments were determined in the dam. Especially for $\mathrm{Cu}$, this pattern might be associated with two main factors: (1) the copper sulfate application which predominantly takes place in this area and (2) the presence of important binding phases in higher levels as fine-grained sediments and organic matter. In Barra Bonita, Igaratá, and Itupararanga reservoirs, there was no clear gradient for metal upstream-downstream. All these variations might be associated to both the dynamics of operation of these water bodies and the land use and occupation of the river basins.

\section{Conclusions}

The data revealed that both intra- and inter-reservoir spatial heterogeneity were mainly influenced by anthropogenic activities, which were associated with trophic state increases in the Broa, Salto Grande, and Barra Bonita reservoirs. There was evidence of anthropogenic metal contamination, especially in the Rio Grande, Barra Bonita, and Salto Grande reservoirs. Not all reservoirs or metals had highest metal levels in the dam area as expected; this was possibly associated to geological characteristic as well as to different anthropic impact levels in the watersheds. Besides the signs of contamination, the use of SQGVs indicated that toxicity was likely to occur in the Rio Grande and Barra Bonita reservoirs. However, the environmental conditions, together with the characteristics of the water and sediment, suggested that the metals would not be present in bioavailable forms. Ecotoxicological tests are recommended for these ecosystems, because the absence of bioavailability does not mean that the metals do not exert toxicity. This research is important for improving understanding of the functioning and dynamics of reservoirs, as well as for assisting in the establishment of water resources monitoring and management programs, since different degrees of contamination can require different ways of operating and treating the system. Given the high number of water bodies potentially affected by metal contamination, we believe that this work can be useful in other geographical contexts.

\section{References}

Arnason, J. G., \& Fletcher, B. A. (2003). A 40+ year record of Cd, $\mathrm{Hg}, \mathrm{Pb}$, and $\mathrm{U}$ deposition in sediments of Patroon Reservoir, Albany County, NY, USA. Environmental Pollution, 123(3), 383-391. https://doi.org/10.1016/S0269-7491(03)00015-0.

Becker, V., Caputo, L., Ordóñez, J., Marcé, R., Armengol, J., Crossetti, L. O., \& Huszar, V. L. M. (2010). Driving factors of the phytoplankton functional groups in a deep Mediterranean reservoir. Water Research, 44(11), 33453354. https://doi.org/10.1016/j.watres.2010.03.018.

Beghelli, F. G. S., Frascareli, D., Pompeo, M. L. M., \& MoschiniCarlos, V. (2016). Trophic state evolution over 15 years in a tropical reservoir with low nitrogen concentrations and cyanobacteria predominance. Water, Air and Soil Pollution, 227, 94.

Belluta, I., Jesus, S. A. D. E., Vieira, M. P., Corrêa, N. M., Rall, V. L. M., \& Valente, J. P. S. (2016). Water quality, organic loading and nutrient loading in the Mouth of Cascata Brook: the subbasin contribution to Barra Bonita Reservoir (Tietê River-São Paulo (Brazil)). Journal Brazilian of Physical Geography, 9, 305-318.

Bing, H., Zhou, J., Wu, Y., Wang, X., Sun, H., \& LI, R. (2016). Current state, sources, and potential risk of heavy metals in sediments of Three Gorges Reservoir, China. Environmental Pollution, 214, 485-496. https://doi.org/10.1016/j. envpol.2016.04.062.

Burger, D. F., Hamilton, D. P., Pilditch, C. A., \& Gibbs, M. M. (2007). Benthic nutrient fluxes in a eutrophic, polymictic lake. Hydrobiologia, 584(1), 13-25. https://doi.org/10.1007 /s10750-007-0582-0.

Buzelli, G. M., \& Cunha-Santino, M. B. D. (2013). Diagnosis and analysis of water quality and trophic state of Barra Bonita reservoir, SP. Journal Environmental \& Water, 8(1), 186205.

Cardoso-Silva, S., Nishimura, P. Y., Padial, P. R., Mariani, C. F., Moschini-Carlos, V., \& Pompêo, M. L. M. (2014). Compartmentalization and water quality: billings reservoir case. Bioikos, Campinas, 28, 31-43.

Cardoso-Silva, S., Ferreira, P. A. L., Moschini-Carlos, V., Figueira, R. C. L., \& Pompeo, M. L. M. (2016a). Temporal and spatial accumulation of heavy metals in the sediments at Paiva Castro Reservoir (São Paulo, Brazil). Environmental Earth Sciences, 75, 1-16.

Cardoso-Silva, S., Silva, D. C. V. R., Lage, F., Rosa, A. H., Moschini-Carlos, V., \& Pompeo, M. L. M. (2016b). Metals in sediments: bioavailability and toxicity in a tropical reservoir used for public water supply. Environmental Monitoring and Assessment (Dordrecht. Online), 188, 310.

Carlson, R. E. (1977). A trophic state index for lakes. Limnology and Oceanography., 22, 261-269.

CCME, Canadian Council of Ministers of the Environment. (1999). Canadian sediment quality guidelines for the protection of aquatic life - protocol for the derivation of Canadian Sediment Quality Guidelines for the Protection of Aquatic Life (CCME EPC-98E). 35 p.

Chapman, P. M., Wang, F., Adams, W. J., \& Green, A. (1999). Appropriate applications of sediment quality values for metals and metalloids. Environmental Science \& Technology, 33, 3937-3941. 
CIS-Common Implementation Strategy for The Water Framework Directive (2000/ 60/EC) (2000). Guidance on typology, reference conditions and classification systems for transitional and coastal waters, $119 \mathrm{p}$.

Cole, G. A. (1994). Textbook of limnology. Illinois: Waveland Press Inc., Prospect Heights.

Depaula, F. C., \& Mozeto, A. A. (2001). Biogeochemical evolution of trace elements in a pristine watershed in the Brazilian southeastern coastal region. Applied Geochemistry, 16(9), 1139-1151. https://doi.org/10.1016/S0883-2927(00)000846.

Di Toro, D. M., Mahony, J. D., Hansen, D. J., Scott, K. J., Hicks, M. B., Mayr, S. M., \& Redmon, M. S. (1990). Toxicity of cadmium in sediments: the role of acid volatile sulfide. Environmental Toxicology and Chemistry, 9(12), 14871502. https://doi.org/10.1002/etc.5620091208.

Díez, E. G., Corella, J. P., Adatte, T., Thevenon, F., \& Loizeau, J. L. (2017). High-resolution reconstruction of the 20th century history of trace metals, major elements, and organic matter in sediments in a contaminated area of Lake Geneva, Switzerland. Applied Geochemistry, 78, 1-11. https://doi. org/10.1016/j.apgeochem.2016.12.007.

Dornfeld, C. B.; Espindola, E.L.G.; Leite, M. A.; Nogueira, A.M. (2001). Acute toxicity bioassays with sediment from the Salto Grande reservoir (Americana, SP, Brazil) using Daphnia similis and Chironomus xanthus.In: IV Reunión Anual de SETAC Latinoamérica Oportunidades para la protección ambiental en América Latina, 2001, Buenos Aires. IV Reunión Anual de SETAC Latinoamérica Oportunidades para la protección ambiental en América Latina.

Dornfeld, C. B., Espindola, E. L. G., \& Leite, M. A. (2005). Evaluation of eutrophication and its relationship with Chironomidae in the Atibaia river and Salto Grande reservoir (Americana, SP-Brazil). Journal Brazilian of Water Resources, Porto Alegre-RS, 10, 53-62.

Eaton, A. D., Clesceri, L. S., Rice, E. W., Greenberg, A. E., \& Franson, M. A. H. A. (2005). APHA: standard methods for the examination of water and wastewater. Washington, DC: Centennial Edition., APHA, AWWA, WEF.

Fagnani, E., Guimarães, J. R., Mozeto, A. A., \& Fadini, P. S. (2011). Acid volatile sulfides and simultaneously extracted metals in the assessment of freshwater sediments. New Chemistry, 34, 1618-1628.

Flemming, C. A., \& Trevors, J. T. (1989). Copper toxicity and chemistry in the environment: a review. Water, Air, and Soil Pollution, 44(1-2), 143-158. https://doi.org/10.1007 /BF00228784.

Fonseca, M. F., \& Matias, L. F. (2014). Analysis of earth and clinographic component use by geoprocessment: the environment of Salto Grande-SP reservoir. Geography Bulletin, 32(3), 48-60.

Förstner, U. E., \& Wittman, G. T. W. (1983). Metal pollution in aquatic environment (484p). Berlin: Springer-Verlag.

Frascareli, D., de Souza Beghelli, F. G., Da Silva, S. C., \& Moschini-Carlos, V. (2015). Spatial and seasonal heterogeneity of limnological variables in Itupararanga reservoir associated with the land use in the Bacia do Alto Sorocaba-SP. Journal Enviromental \& Water, 10, 771-781.

Gao, Q., Li, Y., Cheng, Q., Yu, M., Hu, B., Wang, Z., \& Yu, Z. (2016). Analysis and assessment of the nutrients, biochemical indexes and heavy metals in the Three Gorges Reservoir, China, from 2008 to 2013. Water Research, 92, 262-274. https://doi.org/10.1016/j.watres.2015.12.055.

Hammer, Ø., Dat, H., \& Ryan, P. D. (2001). PAST: paleontological statistics software package for education and data analysis. Palaeontol Electron, 4(1), 9.

He, Y., Men, B., Yang, X., Li, Y., Xu, H., \& Wang, D. (2017). Investigation of heavy metals release from sediment with bioturbation/bioirrigation. Chemosphere.

Huszar, V. L. M., Silva, L. H. S., Marino, M., Domingos, P., Sant'Anna, C. L. (2000). Cyanoprokaryote assemblages in eight productive tropical Brazilian waters. In: The Trophic Spectrum Revisited (pp. 67-77). Netherlands: Dordrecht.

INAG, I.P 2009. Manual para a avaliação da qualidade biológica da água. Protocolo de amostragem e análise para o Fitoplâncton. Ministério do Ambiente, do Ordenamento do Território e do Desenvolvimento Regional. Instituto da Água, I.P.

Iqbal, J., Saleem, M., \& Shah, M. H. (2016). Spatial distribution, environmental assessment and source identification of metals content in surface sediments of freshwater reservoir, Pakistan. Chemie der Erde, 76, 171-177.

Jain, C. K., Malik, D. S., \& Yadav, R. (2007). Metal fractionation study on bed sediments of Lake Nainital, Uttaranchal, India. Environmental Monitoring and Assessment, 130(1-3), 129139. https://doi.org/10.1007/s10661-006-9383-6.

Kimmel, B.L., Lind, O.T., Paulson, L.J. (1990). Reservoir primary production In: Thornton, K.W., Kimmel, B.L. \& Payne, F.E. (Eds.), Reservoir limnology: ecological perspectives. New York: John Wiley \& Sons, Inc.

Lamparelli, M. C. (2004). Trophic status in São Paulo state water bodies evaluation of monitoring methodologies. $238 \mathrm{f}$. Doctoral thesis (phD in ecology apply)—São Paulo University, Institute of Biosciences, São Paulo.

Landajo, A., Arana, G., De Diego, A., Etxebarria, N., Zuloaga, O., \& Amouroux, D. (2004). Analysis of heavy metal distribution in superficial estuarine sediments (estuary of Bilbao, Basque Country) by open-focused microwave-assisted extraction and ICP-OES. Chemosphere, 56(11), 1033-1041. https://doi.org/10.1016/j.chemosphere.2004.06.005.

Legendre, P., \& Legendre, L. (1998). Numerical ecology (p. 853). Amsterdam: Elsevier Science.

Leite, M. A., Espindola, E. L. G., \& Dornfeld, C. B. (2004). Quantification of metals in the water of the Salto Grande Reservoir (Americana, SP). In E. L. G. Espindola, M. A. Leite, \& C. B. Dornfeld (Eds.), Salto Grande reservoir (Americana, SP): characterization, impacts and management proposals (pp. 55-70). São Carlos: Rima Editora.

Li, H., Song, C. L., Cao, X. Y., \& Zhou, Y. Y. (2016). The phosphorus release pathways and their mechanisms driven by organic carbon and nitrogen in sediments of eutrophic shallow lakes. Science of the Total Environment, 572, 280288. https://doi.org/10.1016/j.scitotenv.2016.07.221.

Mariani, C. F., \& Pompêo, M. (2008). Potentially bioavailable metals in sediment from a tropical polymictic environment, Rio Grande Reservoir, Brazil. Journal of Soils and Sediments, 8(5), 284-288. https://doi.org/10.1007/s11368008-0018-0.

Mayer, T., Rosa, F., Mayer, R., \& Charlton, M. (2006). Relationship between the sediment geochemistry and phosphorus fluxes in a Great Lakes coastal marsh, Cootes 
Paradise, ON, Canada. Water, Air, \& Soil Pollution: Focus, 6(5-6), 495-503. https://doi.org/10.1007/s11267-006-90336.

Meguro, M. (2000). Ecology methods. São Paulo. Methodology handbook for BIE discipline-321. Institute of Biosciences, USP, 117.

Moschini-Carlos, V., Bortolli, S., Pinto, E., Nishimura, P. Y., Freitas, L. G., Pompêo, M. L. M., \& Dorr, F. (2009). Cyanobacteria and cyanotoxin in the Billings Reservoir (São Paulo, SP, Brazil). Limnetica, 28(2), 227-236.

Mozeto, A. A., Yamada, T. M., Morais, C. R., Nascimento, M. R. L., Fadini, P. S., Torres, R. J., Sueitt, A. P. E., \& Faria, B. M. (2014). Assessment of organic and inorganic contaminants in sediments of an urban tropical eutrophic reservoir. Environmental Monitoring and Assessment, 186(2), 815834. https://doi.org/10.1007/s10661-013-3419-5.

Navarro, E., Bacardit, M., Caputo, L., Palau, T., \& Armengol, J. (2006). Limnological characterization and flow patterns of a three-coupled reservoir system and their influence on Dreissena polymorpha populations and settlement during the stratification period. Lake and Reservoir Management, 22(4), 293-302. https://doi.org/10.1080/07438140609354363.

Oksanen, J., F. Guillaume Blanchet, Roeland Kindt, Pierre Legendre, R. B. O'hara, G.L. Simpson, P. Solymos, M. H. H. Stevens, Helene Wagner. (2011). vegan: Community ecology package. R package version 1.17-6. http://CRAN.Rproject.org/package=vegan.

Piper, C. S. (1947). Soil and plant analysis. New York: Interscience Publishers.

Pompêo, M. L. M., \& Moschini-Carlos, V. (2003). Aquatic macrophytes and periphyton: ecological and methodological aspects. São Carlos: RiMa.

Pompêo, M., Padial, P. R., Mariani, C. F., Cardoso-Silva, S., Moschini-Carlos, V., da Silva, D. C. V. R., Paiva, T. C., Brazil, D. E., \& Brandimarte, A. L. (2013). Bioavailability of metals in the sediment of an urban tropical reservoir (Guarapiranga reservoir-São Paulo, Brazil): is there potential toxicity and spatial heterogeneity? Geochimica Brasiliensis., 27(2), 104-119. https://doi.org/10.5327 /Z0102-9800201300020003.

Pompêo, M., Gonçalves, P. K., Moschini-Carlos, V., CardosoSilva, S., de Lucia Lobo, F., do Amaral Meirinho, P., Bitencourt, M. D., \& Meirelles, S. T. (2015a). Spatial horizontal heterogeneity of quality water in Rio Grande reservoir, Billings Complex, São Paulo, Brasil. In M. Pompêo, V. Moschini-Carlos, P. Y. Nishimura, S. Cardoso-Silva, \& J. C. López-Doval (Eds.), Ecology of reservoir and interfaces (Vol. 1, 1ed ed., pp. 82-95). São Paulo: Institute of Biosciences.

Pompêo, M.; Ruiz, J.P.C.; Moschini-Carlos, V.; Marcé, R.; Nishimura, P.Y.; Armengol, J.; López, P. (2015b). Chemical elements in superficial sediments of five reservoirs in the catalonia and aragon regions (Spain): is there an anthropogenic contribution? In: Pompêo, M., Moschini-Carlos, V., Nishimura, P.Y., Cardoso-Silva, S., López-Dorval, J. (Eds.), Ecologia de reservatórios e interfaces.

Rodgher, S., Espíndola, E. L. G., Rocha, O., Fracácio, R., Pereira, R. H. G., \& Rodrigues, M. H. S. (2005). Limnological and ecotoxicological studies in the cascade of reservoirs in the Tietê river (São Paulo, Brazil). Brazilian Journal of Biology,
65(4), 697-710. https://doi.org/10.1590/S151969842005000400017.

Sauvé, S., Cook, N., Hendershot, W. H., \& Mcbride, M. B. (1996). Linking plant tissue concentrations and soil copper pools in urban contaminated soils. Environmental Pollution, 94(2), 153-157. https://doi.org/10.1016/S0269-7491(96)00081-4.

Sevindik, T. O., Çelik, K., \& Naselli-Flores, L. (2017). Spatial heterogeneity and seasonal succession of phytoplankton functional groups along the vertical gradient in a mesotrophic reservoir. Annales de Limnologie-International Journal of Limnology, 53, 129-141 EDP Sciences.

Sisinno, C. L., \& Moreira, J. C. (1996). Evaluation of contamination and environmental pollution in the area of influence of the controlled landfill of Morro do Céu, Niterói, Brazil. Handbook Public Health, 12(4), 515-523.

Smith, W. S., Espindola, E. L. G., \& Rocha, O. (2014). Environmental gradient in reservoirs of the medium and low Tietê River: limnological differences through the habitat sequence. Acta Limnological Brasiliensia Rio Claro, 26, 73 88.

SNIS - Sistema Nacional de Informação sobre Saneamento (2016) Diagnóstico dos serviços de água e esgoto de 2016. Available in: http://www.snis.gov.br/diagnostico-agua-e-esgotos/154diagnostico-ae-2016 Accessed 15 Feb 2016.

Soares, M. C. S., Marinho, M. M., Huszar, V. L., Branco, C. W., \& Azevedo, S. M. (2008). The effects of water retention time and watershed features on the limnology of two tropical reservoirs in Brazil. Lakes \& Reservoirs: Research \& Management, 13(4), 257-269. https://doi.org/10.1111 j.1440-1770.2008.00379.x.

Søndergaard, M., Jensen, J. P., \& Jeppesen, E. (1999). Internal phosphorus loading in shallow Danish lakes. In: Hydrobiologia, 408(409), 145-152.

Souza, V. A., \& Wasserman, J. C. (2015). Distribution of heavy metals in sediments of a tropical reservoir in Brazil: sources and fate. Journal of South American Earth Sciences, 63, 208216. https://doi.org/10.1016/j.jsames.2015.07.014.

Sundaray, S. K., Nayak, B. B., Lin, S., \& Bhatta, D. (2011). Geochemical speciation and risk assessment of heavy metals in the river estuarine sediments - a case study: Mahanadi basin, India. Journal of Hazardous Materials, 186(2-3), 1837-1846. https://doi.org/10.1016/j.jhazmat.2010.12.081.

Superville, P. J., Prygiel, E., Mikkelsen, O., \& Billon, G. (2015). Dynamic behaviour of trace metals in the Deûle River impacted by recurrent polluted sediment resuspensions: from diel to seasonal evolutions. Science of the Total Environment, 506, 585-593.

Sutherland, R. A. (2000). Bed sediment-associated trace metals in an urban stream, Oahu. Hawaii. Enviromental Geology, 39(6), 611-627. https://doi.org/10.1007/s002540050473.

Thornton, K. W., Kimmel, B. L., \& Payne, F. E. (1990). Perspectives on reservoir limnology. In K. W. Thornton, B. L. Kimmel, \& F. E. Payne (Eds.), Reservoir limnology: ecological perspectives. New York: Wiley-Interscience.

Tomlinson, D. L., Wilson, J. G., Harris, C. R., \& Jeffrey, D. W. (1980). Problems in the assessment of heavy-metal levels in estuaries and the formation of a pollution index. Helgoländer Meeresuntersuchungen, 33(1), 566-575. https://doi. org/10.1007/BF02414780.

Tundisi, J. G., Matsumura-Tundisi, T., Tundisi, J. E. M., Blanco, F. P., Abe, D. S., Contri Campanelli, L., Sidagis-Galli, G. A., 
Silva, V., \& Lima, C. P. P. (2015). A bloom of cyanobacteria (Cylindrospermopsis raciborskii) in UHE Carlos Botelho (Lobo/Broa) reservoir: a consequence of global change? Brazilian Journal of Biology, 75(2), 507-508. https://doi. org/10.1590/1519-6984.24914.

Tzoraki, O., Karaouzas, I., Patrolecco, L., Skoulikidis, N., \& Nikolaidis, N. P. (2015). Polycyclic aromatic hydrocarbons (PAHs) and heavy metal occurrence in bed sediments of a temporary river. Water, Air, \& Soil Pollution, 226(12), 1-19.

US EPA (U.S. Environmental Protection Agency) (2016). Table of Regulated Drinking Water Contaminants. Regulated drinking water contaminants. Dados online, 2016. Acessado em: 01 de setembro de 2016. Disponível em: https://www.epa. gov/ground-water-and-drinking-water/table-regulateddrinking-water-contaminants\#Inorganic.

US EPA, United States Environmental Protection Agency (2005). Procedure for the derivation of Equilibrium Partitioning Sediment Benchmarks (ESBs) for the protection of benthic organisms: metal mixtures (cadmium, cooper, lead, nickel, silver and zinc. Office of Research and Development. Washington, D. C.: (EPA-600-R-02-011).121.

US EPA United States Environmental Protection Agency. Method 3050B (1996). Acid digestion of sediments, sludges and soil. Revision 2. December.

Wang, G., Yinglan, A., Jiang, H., Fu, Q., \& Zheng, B. (2015). Modeling the source contribution of heavy metals in surficial sediment and analysis of their historical changes in the vertical sediments of a drinking water reservoir. Journal of Hydrology, 520, 37-51. https://doi.org/10.1016/j. jhydrol.2014.11.034.
Wei, G., Yang, Z., Cui, B., Li, B., Chen, H., Bai, J., \& Dong, S. (2009). Impact of dam construction on water quality and water self-purification capacity of the Lancang River, China. Water Resources Management, 23(9), 1763-1780. https://doi.org/10.1007/s11269-008-9351-8.

Wengrat, S., Bicudo, D., \& De, C. (2011). Spatial evaluation of water quality in an urban reservoir (Billings Complex, southeastern Brazil). Acta Limnological. Brasiliensia, Rio Claro, 23(2), 200-216.

Wetzel, R. G. (2001). Limnology: lake and river ecosystems, 3rd ed. San Diego: Gulf professional publishing, Academic Press.

Wetzel, R. G., \& Likens, G. E. (1991). Limnological analyses. New York: Springer-Verlag. https://doi.org/10.1007/978-14757-4098-1.

Zahra, A., Hashmi, M. Z., Malik, R. N., \& Ahmed, Z. (2014). Enrichment and geo-accumulation of heavy metals and risk assessment of sediments of the Kurang Nallah-feeding tributary of the Rawal Lake reservoir, Pakistan. Science of the Total Environment, 470-471, 925-933. https://doi. org/10.1016/j.scitotenv.2013.10.017.

Zhang, Z., Juying, L., \& Mamat, Z. (2016). Sources identification and pollution evaluation of heavy metals in the surface sediments of Bortala River, Northwest China. Ecotoxicology and Environmental Safety, 126, 94-101. https://doi.org/10.1016 j.ecoenv.2015.12.025.

Zhu, L., Liu, J., Xu, S., \& Xie, Z. (2017). Deposition behavior, risk assessment and source identification of heavy metals in reservoir sediments of Northeast China. Ecotoxicology and Environmental Safety, 142, 454-463. https://doi. org/10.1016/j.ecoenv.2017.04.039. 